\title{
THE WORLD OF INNOVATIONS
}

https://doi.org/10.15407/scine16.02.080

KOBETS, V.', YATSENKO, V. ${ }^{2}$, MAZUR, A. ${ }^{1}$, and ZUBRII, M. ${ }^{1}$

'Kherson State University, 27, Universitetska St., Kherson, 73003, Ukraine, +380 55232 6782, kipiekedu@gmail.com

${ }^{2}$ Taras Shevchenko National University of Kyiv, 90-A, Vasylkivska St., Kyiv, 03022, Ukraine, +380 445213578 , decanat_econom@univ.kiev.ua

\section{DATA ANALYSIS OF PERSONALIZED INVESTMENT DECISION MAKING USING ROBO-ADVISERS}

Introduction. Nowadays, the problem of the optimal balance between consumption and savings, transformed into investments is solved by using automated systems for making investment decisions, such as robo-advice services which have the mathematical algorithm based on the main principles of consumption-savings theories.

Problem Statement. The task assignment of developed IT service is to maintain a constant level of client's consumption during life-long period through automated analysis of how much he/she has to consume and save each year. Results of consumption and savings proposals can be modified if initial financial data changes.

Purpose. To develop investment plan of investors' profiles taking into account their risk preferences using data analysis of robo-adviser service.

Materials and Methods. SWOT-analysis of robo-advice (RA) services and comparative characteristics of robo-advisers explain advantage of RA services. Microservice for calculating stable consumption, finance consulting model of robo-advisor to ensure a constant level of consumption for the client are developed using the following technologies: Python 3.6, Django 2.0, Django Rest framework, AngularJs, HTML5, CSS 3, Bootstrap.

Results. We considered consumption-saving ratio in economics, emerging trends of robo-advice (RA) services for making investment decisions. A mathematical model of robo-advisor in long-run period was developed and the support of investment decision making was described using micro-service of robo-advisor.

Conclusions. The development $R A$ is intended primarily for private persons (investors) who invest in longterm financial instruments in order to provide them with a permanent passive income based on their chosen savings period and the moment of retirement.

Keywords : robo-advisor, data analysis, long life decision making, annuity.

The problem of the optimal balance between consumption and savings, transformed into investments, is one of the most important issues on all levels of economic system. This is explained by the fact that the equivalence between consumer and savings flows provides for internal and external equilibrium in the economics, and, therefore, a balanced economic growth and increase of economic and social welfare. As a result, the scholarly ap-

Citation: Kobets, V., Yatsenko, V., Mazur, A., and Zubrii, M. Data Analysis of Personalized Investment Decision Making Using Robo-Advisers. Sci. innov. 2020. V. 16, no. 2. P. 80-93. https://doi.org/10.15407/ scine16.02.080 
paratus of the subject is characterized by the variability of approaches and views of top economists, which sometimes supplement, and often directly contradict each other. However, the bottleneck of the scientific research is the analysis of consumer spending and saving patterns through adaptive or rational expectations theories. Usage of these theories is complicated in modern economic conditions, characterized by high levels of future uncertainty, volatility of the main economic indicators, variability of market condition and limited ability of a person to process modern data independently, etc. In this case, the ability of economic actors to make rational economically justified solutions dramatically reduces which determines the necessity to use automated systems for making investment decisions. The most popular ones among such automated systems are roboadvice services which have the mathematical algorithm based on the main principles of consumption-savings theories.

The purpose of this paper is to develop investment plan of investors' profiles taking into account their risk preferences using data analysis of roboadviser service.

\section{ROBO-ADVICE SERVICES AND ITS EMERGING TRENDS}

The concept of "robo-advice" means the use of automation and digital techniques in order to build and manage portfolios of exchange-traded funds (ETFs) and other instruments for investors [1]. On the other hand, it can be described as the system to make investment decision exclude human psychology or emotion [2] by limitation of the trap of repeating unfavourable previous decisions [3]; an artificial intelligence system that makes decisions based on algorithms by collecting vast quantities of big data [4]. The main principle of roboadvice services means completing a simple profile and risk tolerance questionnaire online and receive a recommended portfolio, composed mostly of low-cost exchange-traded funds (ETFs).

Robo-adviser represents an online service that helps the client to form an investment portfolio

\section{Table 1. SWOT-Analysis of Robo-Advice Services}

\section{Strengths}

Increased productivity

Low commission and fees

High accessibility by customers

Streamlining the account opening process, ability to transfer assets

No requirement for a deep financial background

Increased transparency

Diversification of portfolios by using ETFs

It is the ideal model for clients with simple needs

Monitoring, rebalancing and reporting on portfolios

Appealing to non-traditional clients (young clients)

Offers easy-to-use tools simplifying the client experience

\section{Opportunities}

Adding new capabilities;

Attracting assets that are not currently in-house at wealth management firms;

Receiving synergy and added value in case of cooperation with financial advisers;

Expanding interest in passive investing;

Assimilating multiple goals (college savings, retirement, estate planning and the need for health care and/or long term care coverage);

Including extra assets (equities, fixed income, hedge funds and real estate);

Helping clients to understand their portfolios;

Considering the client's complexities by adapting questions based on earlier responses.

\section{Weaknesses}

It does not meet all needs of investors

It does not suit every investor

It uses simple surveys to profile clients and to assess their needs

It proposes fairly basic capabilities

It has minimal ability to explain complex topics, and no ability at all to follow up with questions and make recommendations based on the answers

\section{Threats}

Failure of trust to automation and digital techniques Necessity of face-to-face interaction between clients and advisors

and subsequently manage it (make adjustments, advice, etc.). The consulting robot is able to analyze the user's needs and his/her risk attitude, make an investment model for him and gradually implement it by buying and selling securities in 
Table 2. Comparative Characteristics of Robo-Advisers

\begin{tabular}{|c|c|c|c|c|c|}
\hline Day & Robo-advisor & Features and positioning & Marketing stock & $\begin{array}{c}\text { Minimal } \\
\text { amount }\end{array}$ & Commission \\
\hline $\begin{array}{l}\text { Best in total } \\
\text { indicators with } \\
\text { the function of } \\
\text { minimizing taxes }\end{array}$ & Wealthfront & $\begin{array}{l}\text { Optimization and inde- } \\
\text { xation of taxes for accounts } \\
\text { over USD } 100000\end{array}$ & $\begin{array}{l}\text { Up to USD } 10000 \\
\text { no commission for } \\
\text { annual maintenance }\end{array}$ & USD 500 & $0.25 \%$ per year \\
\hline $\begin{array}{l}\text { Best in Total } \\
\text { Indicators }\end{array}$ & Betterment & $\begin{array}{l}\text { With the help of a user- } \\
\text { friendly interface, it is } \\
\text { possible to form a } \\
\text { portfolio efficiently and } \\
\text { cheaply }\end{array}$ & $\begin{array}{l}\text { First } 6 \text { months free } \\
\text { of charge }\end{array}$ & USD 0 & $\begin{array}{c}0.15-0.35 \% \text { per } \\
\text { year }\end{array}$ \\
\hline $\begin{array}{l}\text { With minimal } \\
\text { commissions }\end{array}$ & WiseBanyan & Additional services paid & None & USD 10 & 0 \\
\hline $\begin{array}{l}\text { With minimal } \\
\text { commissions }\end{array}$ & $\begin{array}{l}\text { Charles } \\
\text { Schwab }\end{array}$ & $\begin{array}{l}\text { Recognized leader in the } \\
\text { sphere of asset } \\
\text { management }\end{array}$ & None & USD 5000 & 0 \\
\hline $\begin{array}{l}\text { Specializing in } \\
\text { retirement plan } \\
401 \mathrm{~K}\end{array}$ & FutureAdvisor & $\begin{array}{l}\text { Operates } 401 \mathrm{~K} \text { accounts } \\
\text { serviced by the } \\
\text { investment company } \\
\text { Fidelity and TD } \\
\text { Ameritrade for free }\end{array}$ & $\begin{array}{l}\text { First } 3 \text { months free } \\
\text { of charge }\end{array}$ & USD 10000 & $0.5 \%$ per year \\
\hline $\begin{array}{l}\text { Specializing in } \\
\text { retirement plan } \\
401 \mathrm{~K}\end{array}$ & Blooom & $\begin{array}{l}\text { Manages } 401 \mathrm{~K} \text { accounts } \\
\text { for a fixed fee }\end{array}$ & None & USD 0 & $\begin{array}{l}\text { USD } 5 \text { to USD } 99 \\
\text { per month }\end{array}$ \\
\hline $\begin{array}{l}\text { With the services } \\
\text { of a financial } \\
\text { adviser }\end{array}$ & Vanguard & $\begin{array}{l}\text { Services of the adviser } \\
\text { (manager) }\end{array}$ & None & USD 50000 & $0.30 \%$ per year \\
\hline $\begin{array}{l}\text { With the services } \\
\text { of a financial } \\
\text { adviser and } \\
\text { function of } \\
\text { minimizing taxes }\end{array}$ & $\begin{array}{c}\text { Personal } \\
\text { Capital }\end{array}$ & $\begin{array}{l}\text { Financial Consultant } \\
\text { (Manager) }+ \text { tax } \\
\text { optimization for accounts } \\
\text { over USD } 100000\end{array}$ & None & USD 25000 & $\begin{array}{c}0.49-0.89 \% \text { per } \\
\text { year }\end{array}$ \\
\hline
\end{tabular}

the stock market and other financial instruments. Thus, the robo-adviser actually performs the functions of the "portfolio manager".

The income depends on the amount invested and the degree of investment risk. It is impossible to guarantee a positive and stable profitability when trading financial instruments on the stock exchange. This is a feature of the industry itself, not just this service.

The scale of asset management with robo-advisor continues to be quite insignificant. According to research of Jae Yeon Park and et al. it is two hundred trillion won, while it is expected more than two thousand trillion won in 2020 [2]. According to Deloitte prediction Robo-Advisory services will manage with assets between USD 2.2 trillion and USD 3.7 trillion in 2020. By the year 2025 is expected to rise to over USD 16.0 trillion assets under management [5]. Swot-analysis of RA is demonstrated in Table 1.

Uptrend of robo-advisor development can be explained due to its main parameters: strike price, variety and complexity of investment tools and trust. We assume that new capabilities of robo-advisors and trust will be developed more actively and rapid then the price and commission 
of robo-advice services which means exponential growth and expansion robo-advisors among different types of investors. Nevertheless, now trust is one of the barriers of significant robo-advice services growth. Accenture research indicates that $77 \%$ of wealth management clients trust their financial advisors and want to work with them to grow and manage their wealth. Furthermore, 81\% say that face-to-face interaction is importantthe highest figure of all channels [1]. Customers prefer hybrid solutions, allowing them to search for information and compare available products online, but still request human advisory before committing to an investment [6].

The first such services for retail customers appeared in the US, in 2008. According to the ResearchHQ News specializing in research and ratings, the leaders of this market are American independent robot-advisers Wealthfront (USD 3 billion under management) and Betterment (USD 4.2 billion, 150 thousand customers). In recent years, the number of such online advisers has increased noticeably. There are more than 200 firms offering services of robo-acquiring around the world. Nowadays, they manage about USD 300 billion and, according to forecasts, this graph will grow.

Comparative characteristics of robo-advisers are given in Table 2 and collected from Internet portals that analyze foreign brokerage services. The table in the left column, has the criteria, for which two leader companies are allotted, highlighted.

1. The commissions are charged for the use of robot-advisers, but the costs for the purchase of assets are not taken. Most of robot-advisers use ETFs (Exchange Traded Funds), and managing companies that issue ETFs, charge 0.1 to $0.5 \%$ per annum on funds, depending on the composition of assets. Therefore, it is necessary to add the specified commissions to these prices.

2. Optimization of taxes: the company studies the client's tax profile for the previous period in order to find inefficiently paid deductions (pension, insurance, banks, medicine, stock market), return them and reinvest to the client's account.
3. Retirement plans $401 \mathrm{~K}$ is a popular tool in the US for saving. Money is transferred to these accounts by employers, the assets are not in pension funds, but on dedicated accounts in investment companies, taxes are not withheld from investments. Many people use several options at once, and often the calculation is based on household income.

\section{WHO WILL BENEFIT?}

In well-developed countries, due to significant amount of savings and mature financial markets, the great majority of people have an investment interest, however individual investors usually make investment decisions based on their limited professional knowledge and asymmetric information while institutional investors have stronger professional background and informational support. In this case, robo-advisor is the best tool for private investors the main aim of which is to save the current value of their wealth.

Nevertheless, Jae Yeon Park and et al. pointed out that institutional investors are always exposed to risks caused by diverse unpredictable variables in the financial market [2] which makes robo-advice service suitable also for professional investors with huge amount of investments. In this instance, by applying the Pareto principle, we can assume that robo-advisors can be used in fixed proportions for different types of investors (Fig. 1).

For example, $80 \%$ of investments assets of private investors can be under robo-advice services due to its low commission and using quite simple and clear financial instruments. This strategy according to Pareto-law will gain $20 \%$ of all investment profit, which enables meeting main aim of private investor - save their capital. The rest 20\% of assets can be invested in risky investments with the help of experienced financial consultants, which can receive $80 \%$ of investment profit.

Vice versa, for institutional investors only $20 \%$ assets can be under robo-advice services because of its immature and narrow range of financial and investment instruments since now it does not 


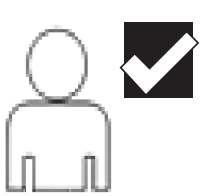

Privat investor
Simple tools + asymmetric

information + low commission

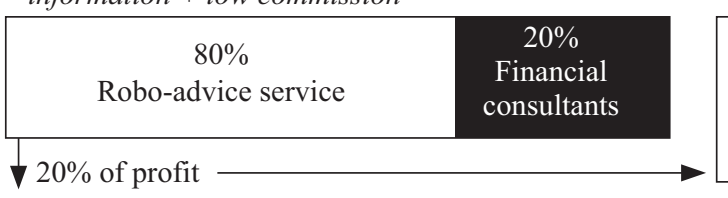

\begin{tabular}{|c|c}
$80 \%$ of profit \\
\hline $\begin{array}{c}20 \% \\
\text { Robo-advice }\end{array}$
\end{tabular} service

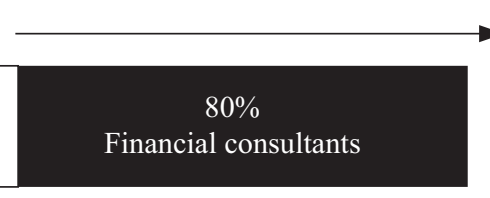

Complex investment tools + professional background + access to the market infomation

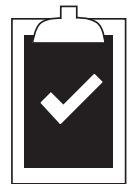

Multiplication of capital

Institutional investor

Fig. 1. The possibility of using robo-advisors by different types of investors

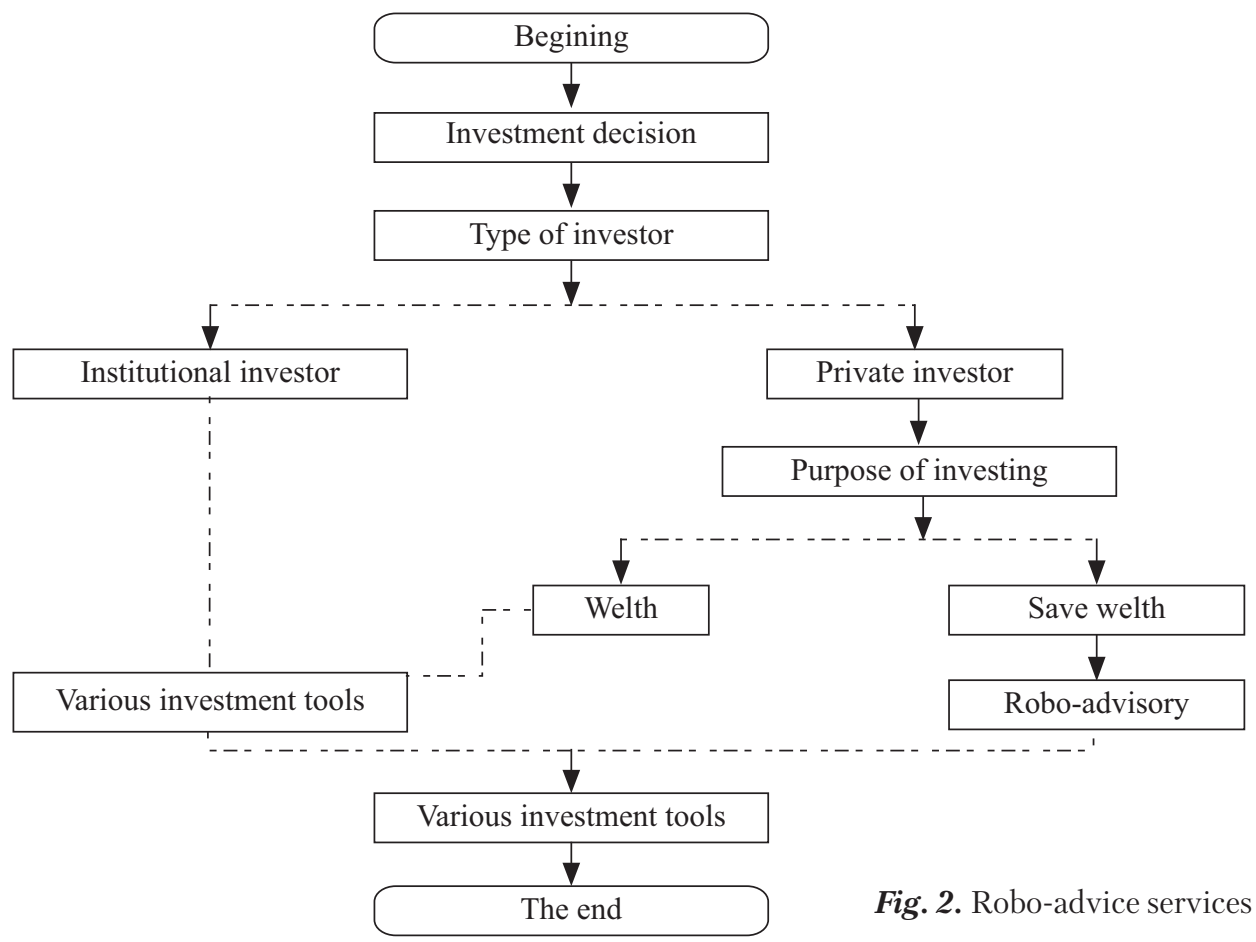

meet the needs of investors with even moderately complex financial lives [1]. At the same time, it can gain $80 \%$ of all investment profit which allows institutional investors to meet all clients' needs in long-run period and keep profitability. The rest amount of assets can be invested in compound instruments based on professional background and classified market information.
Such kind of combination is the most effective to our mind, since complete substitution of human interaction in investing process is impossible. Firstly, robo-advisor capabilities do not cover the whole range of all latest financial and investment instruments, secondly, automated algorithms of a robo-advisor is based on self-reporting processes which can lay down a wrong prin- 
ciple of the robo-advisor working due to incorrect investor self-assessment.

On the other hand, we can mentioned that due to its adaptiveness robo-advice services can be useful for both aggressive and conservative types of investors for which there are two types of robadvisories: active (the investor only receives rebalancing suggestions and decides self-directly about actual execution) and passive (rebalancing is fully quantitative) [6]. The latest generation (Robo-Advisor 4.0) shifts between different asset classes based on changing market conditions and individual investment needs such as profit, risk appetite, and liquidity aspects, monitor and adjust single client portfolios in real time to keep on track with their selected investment strategy [5].

Analyzing short and long-term oriented investments, it can be easily assumed that the roboadvice capability is indeed the better advisor in the long run since the its mathematical algorithm propose adequate investment opportunities based on stable economic trends, excluding the short-term speculative and human being market precedents.

Finally, we can sum up that in the current stage of robo-advisors development this investment tool is more suitable for private investor who is oriented for long-run investment horizon (Fig. 2).

That is why the robot-adviser developed by us is designed primarily for private persons (investors) who invest for a long time in financial instruments in order to secure a permanent passive income at the planned retirement age with the help of a robot consultant.

\section{CLUSTERING ALGORITHM FOR INVESTORS}

Let's consider workflow of Robo-adviser services (Fig. 3). Each user is represented as a vector of four features: risk profile, extracted via standard MiFiD questionnaire, investment goals, sex and age. The first two features are described on fivepoint ordinal scale, from very low to very high, while sex is represented in a binary fashion (male $=0$, female $=1$ ), age is characterized as a numerical variable (Table 3 ).

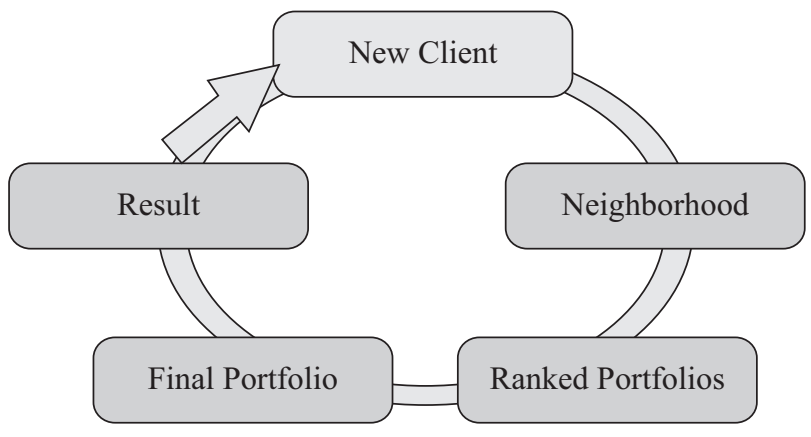

Fig. 3. Workflow of decision making for Robo-adviser services

To distinguish different types of investors (new clients) we can use cluster analysis which help us to reveal main types of most similar investors (neighborhood). After that we can construct correspondence between specific users and investment portfolios. Then we choose best final portfolio which corresponds described features of investor using profitability index (investment goal) and risk attitude (risk profile). RA's service automatically invests in preferred financial instruments to achieve investment goal of client for given investment horizon. Finally client can compare planned goal and achieved result, and revise him or her decision about own investment preferences (profitability and risk).

$k$-means clustering algorithm for investors consists of following steps:

1) Choosing number of clusters $E_{k}$ for given data set of investors;

2) Selection of initial features for reference data which correspond to number of clusters;

Table 3. Description of the Features for Clients of Robo-Adviser Services

\begin{tabular}{|c|c|c|}
\hline Feature & Type & Domain \\
\hline Risk profile & Ordinal & $\begin{array}{c}\text { [very low; low; normal; high; very } \\
\text { high] }\end{array}$ \\
\hline $\begin{array}{l}\text { Investment } \\
\text { goals }\end{array}$ & Ordinal & $\begin{array}{c}\text { [very low; low; normal; high; very } \\
\text { high] }\end{array}$ \\
\hline Sex & Binary & [male, female] \\
\hline Age & Integer & [17...90] \\
\hline
\end{tabular}


3) Calculation distance between features of investors and reference data using following formula (1):

$$
d\left(A_{i} ; E_{k}\right)=\sqrt{\sum_{j=1}^{m}\left(x_{j}-e_{j}\right)^{2}},
$$

where $i$ - index of investor; $x_{j}-$ feature $j$ of investor $i$; $e_{j}$ - initial features for reference data; $n$ - number of investors, $m-$ number of characteristics of each investor;

4) Changing coordinates for reference data $E_{k}$ according to minimal distance between given features of investors and reference data;

$5)$ Defining final values of reference data $E_{k}$;

6) Preparing the classification of objects.

Main types of investors include risk-averse investors (2), risk seeking investors (3) and hybrid type of investors (4) which combines previous ones. These types of investors are correspondingly described by following conditions [24, 25]:

$$
\begin{aligned}
& \left\{\begin{array}{c}
r_{p}=\sum_{i=1}^{n} \sum_{j=1}^{n} x_{i} \cdot x_{j} \cdot v_{i j} \rightarrow \min \\
\sum_{i=1}^{n} x_{i} \cdot d_{i}=m_{p}, \\
\sum_{i=1}^{n} x_{i}=1, x_{i} \geq 0 .
\end{array}\right. \\
& \left\{\begin{array}{c}
r_{p}=\sum_{i=1}^{n} \sum_{j=1}^{n} x_{i} \cdot x_{j} \cdot v_{i j} \rightarrow \min \\
\sum_{i=1}^{n} x_{i} \cdot d_{i}=m_{p}, \\
\sum_{i=1}^{n} x_{i}=1, x_{i} \geq 0 .
\end{array}\right.
\end{aligned}
$$

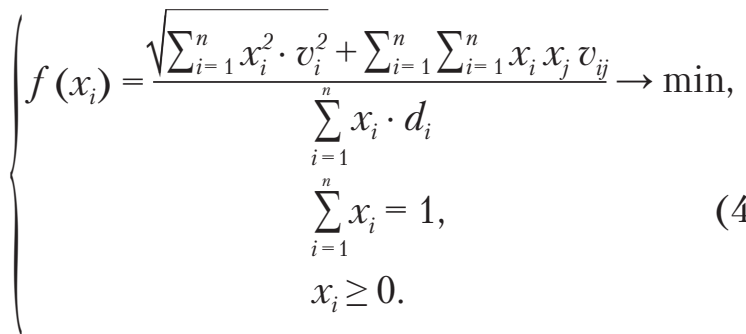

Using cluster of clients and types of investors we map set of users in set of investors' types as described in following section.

A wide series of experiments has been carried out to validate the types of investors for RA ser-
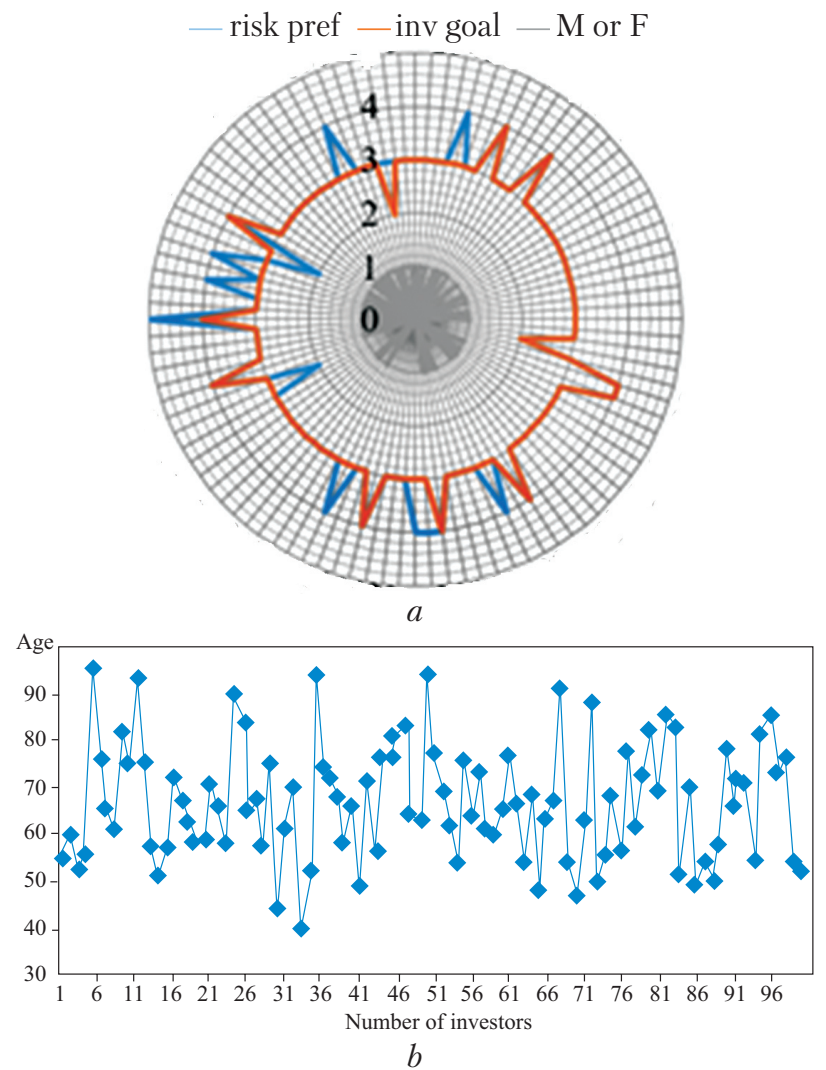

Fig. 4. Characteristics of investment portfolio: $a$ - Data set of features for users of RA; $b$ - Distribution of investors' age

vice using dataset of 100 randomly chosen real (anonymous) users, who choose portfolios between June 2011 and June 2013. This dataset is available for download by Objectway Financial Software (http://www.di.uniba.it/swap/financialrs_data_uniba.zip).

Data set of features for users which invest in portfolio of finance instrument is described on Fig. 4, $a$. In this case we quantified our ordinal data:

- Risk profile = [very low; low; normal; high; very high $]=[1,2,3,4,5]$;

- Investment goals = [very low; low; normal; high; very high $]=[1,2,3,4,5]$,

- Sex $=[$ male, female $]=[0,1]$.

Average values of indicated features are following: Risk profile $=3.16$ (closely to normal), Investment goals $=3.08$ (almost normal), male $=$ $56 \%$ (female $=44 \%$ ) (Fig. 4, $a$ ), age $=66.8$ year (Fig. 4, b). 


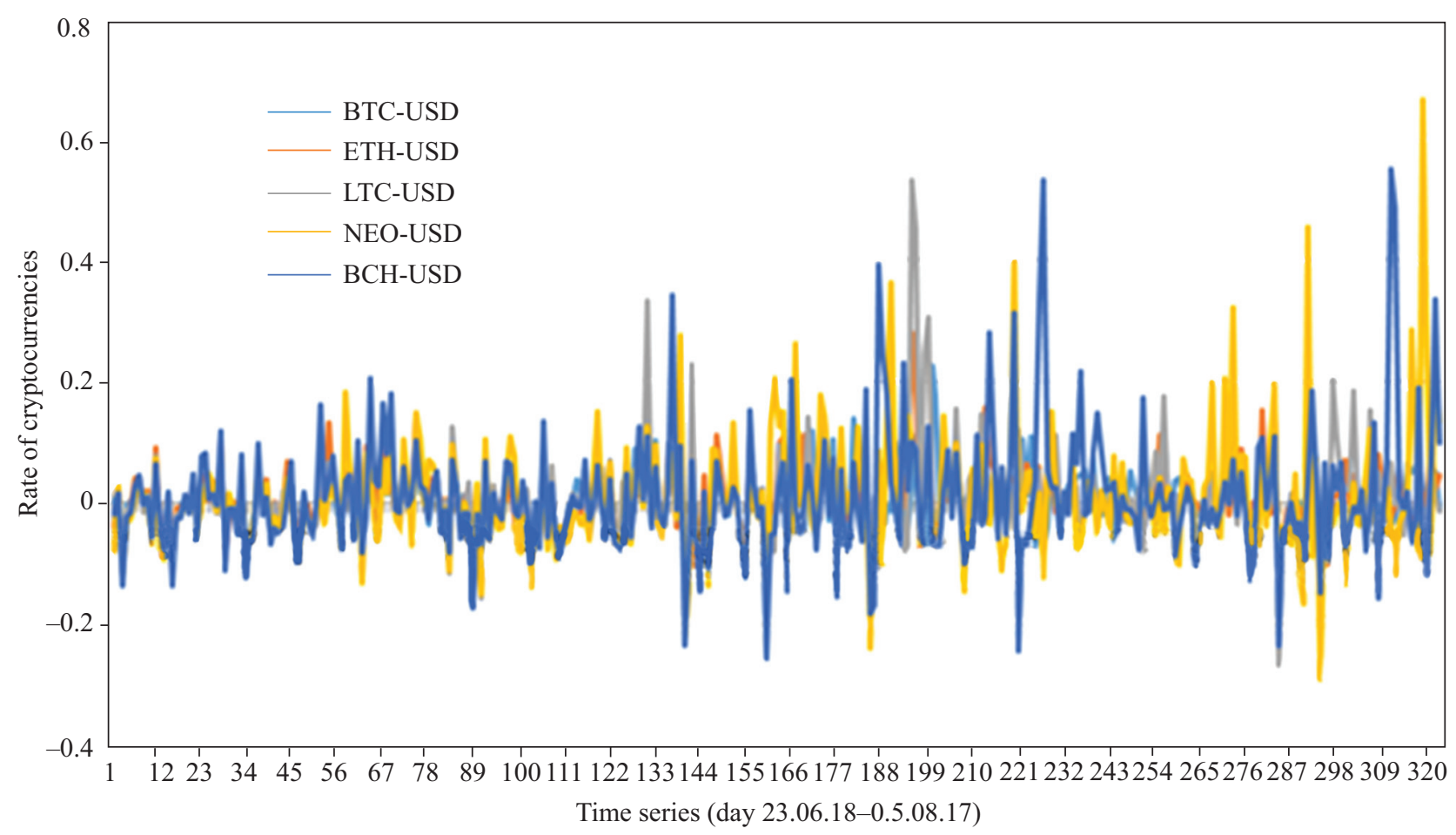

Fig. 5. Rate of 5 main cryptocurrencies for users of RA (23.06.18-05.08.17)

$k$-means clustering algorithm for investors reveal 2 main clusters for our dataset:

1) Active working age and risk-seeking person (man as a rule) who require more than average income (52\%);

2) Retirement pensioner and risk-neutral person (often it is a man) who need income less than average (48\%).

Using open data about rate of financial instruments (Fig. 5), such as cryptocurrencies (https://finance.yahoo.com/cryptocurrencies) and Markowitz model we developed 3 main types of investors:

- $1^{\text {st }}$ type of investor: daily profitability of the risk-averse investor is $0.657 \%$ daily or $24.5 \%$ annually with $0.44 \%$ risk;

- $2^{\text {nd }}$ type of investor: for the risk-seeking investor, the yield will be higher $-0.87 \%$ daily or $31.6 \%$ annually with $1.06 \%$ risk;

- $3^{\text {rd }}$ type of investor: for hybrid type of investor the yield will be $0.45 \%$ daily or $16.5 \%$ annually with $0.28 \%$ risk.
Thus active working age and risk-seeking person is mostly corresponding to $2^{\text {nd }}$ type of investor (profitability index $=31.6 \%$ for robo-advisor service). At the same time retirement pensioner and risk-neutral person is associated with $3^{\text {rd }}$ type of investor (profitability index $=16.5 \%$ for roboadvisor service).

\section{MATHEMATICAL MODEL OF ROBO-ADVISOR IN LONG RUN PERIOD}

Let's consider the work of robo-advisor service based on the following example. Task of the service is to determine the conditions under which an investor can carry out regular consumption both before and after retirement using a personal savings fund. To achieve this, the client of this service should answer the following questions:

1. What is the average annual income of the client?

2. From what age does the client plan to start a personal savings program? 

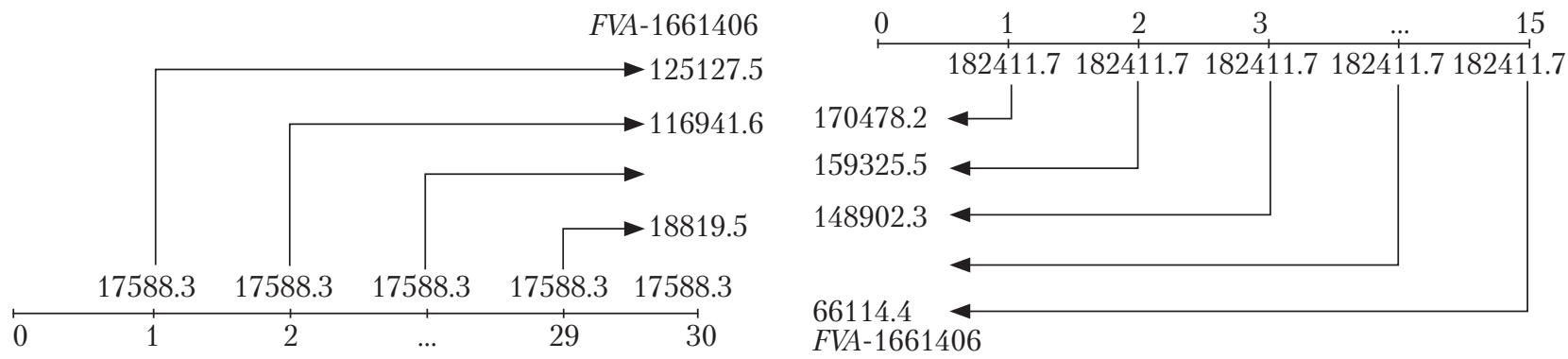

Fig. 6. Future and present values of annuity (FVA and PVA): $a$ - Formation of a personal consumption fund FVA; $b-$ Distribution of personal savings fund $P V A$

3. At what age does the client plan to retire?

4. Up to what age does the client plan to use his/hers personal savings fund?

5. Which average level of 'risk-profit' ('h-i') for financial instruments is preferable for the client?

6. What is the acceptable level of annual consumption $\mathrm{C}^{*}$ for the client?

The task assignment of the IT service is to maintain a constant level of client's consumption during life-long period through automated analysis of how much he/she has to consume and save each year. Example of necessary indicators for data analysis is presented in Table 4. Calculation of distributed income $Y$ for consumption $C$ and savings $S$ :

$$
C=Y-S \text {. }
$$

The task assignment of robo-advisor consists of two parts:

1. To define the annual amount of savings using the future value of annuity FVA:

$$
F V A=S \times \frac{(1+i)^{N_{1}}-1}{i},
$$

Table 4. Indicators of Robo-Advisor Service

\begin{tabular}{|l|c|}
\hline \multicolumn{1}{|c|}{ Indicators } & Value of indicators \\
\hline $\begin{array}{l}\text { The age of the client from which the } \\
\text { personal savings program begins }\end{array}$ & $t_{1}=35$ years \\
$\begin{array}{l}\text { Retirement age of the client } \\
\text { Age up to which the client will use } \\
\text { his savings fund }\end{array}$ & $t_{2}=65$ years \\
$\begin{array}{l}\text { Annual income of the client } \\
\text { The desired annual real interest for } \\
\text { risk-free investments }\end{array}$ & $\begin{array}{l}Y=\text { EUR } 200000 \\
\text { Acceptable level of annual consump- } \\
\text { tion of the client }\end{array}$ \\
\hline
\end{tabular}

where $i$ is the desired annual real interest rate on savings, $N_{1}=t_{2}-t_{1}$ is the accumulation period of a personal savings fund, $S$ is the annual amount saved. After $N_{1}$ years the personal savings of the client will equal $F V A$.

2. To calculate the distribution of the savings fund on constant consumption after retirement using the present value of annuity:

$$
P V A=C \times \frac{1-(1+i)^{-N_{2}}}{i},
$$

Where $i$ is scheduled annual real return on savings, $N_{2}=t_{3}-t_{2}$ is utilization period of a personal savings fund, $C$ is annual constant consumption of the client.

Thus the future and present values of annuities should be equal: $F V A=P V A$ (future and present values of annuities), that is, taking into account (5) we obtain:

$$
C=\frac{Y\left((1+i)^{N_{1}}-1\right)}{(1+i)^{N_{1}}-(1+i)^{-N_{2}}} .
$$

After substitution of the values from Table 4 in formula (8) we get: $C=$ EUR 182411.7 is the annual constant level of consumption, which is not less than the desired expenditure level on the annual consumption of the client $C^{*}=$ EUR 18000 . At the same time, the annual level of client's savings should be EUR 17588.3. If $i<<100 \%$, then we can rewrite (8) as following $C=\frac{Y \cdot N_{1}}{N_{1} \cdot N_{2}}$ and savings fund is $C=\frac{Y \cdot N_{2}}{N_{1} \cdot N_{2}}$.

The formation of a personal consumption fund in graphic form is presented in Fig. 6, $a$. Distribu- 
tion of personal savings funds to a constant consumption level of EUR 182411.7 is presented in Fig. $6, b$.

\section{SUPPORT OF INVESTMENT DECISION MAKING IN LONG-RUN PERIOD VIA SOFTWARE MODULE OF ROBO-ADVISOR}

To implement the practical part we developed a program module as web cloud service of roboadvisor using Python Django technology and template of user interface Admin LTE. In its final form the robo-advisor will have the architecture depicted in Fig. 7.

The overview of the practical module is the following: the application is presented in following figures. Firstly, user needs to pass the registration or if he has already registered - $\log$ in to the service (Fig. 8).

Then, the user has to pass two questionnaires on the website.

On first questionnaire page, the user has to enter firstly the input data required for further calculations, such as:

- Risk profile;

- Investment goals;

- Sex;

- Age.

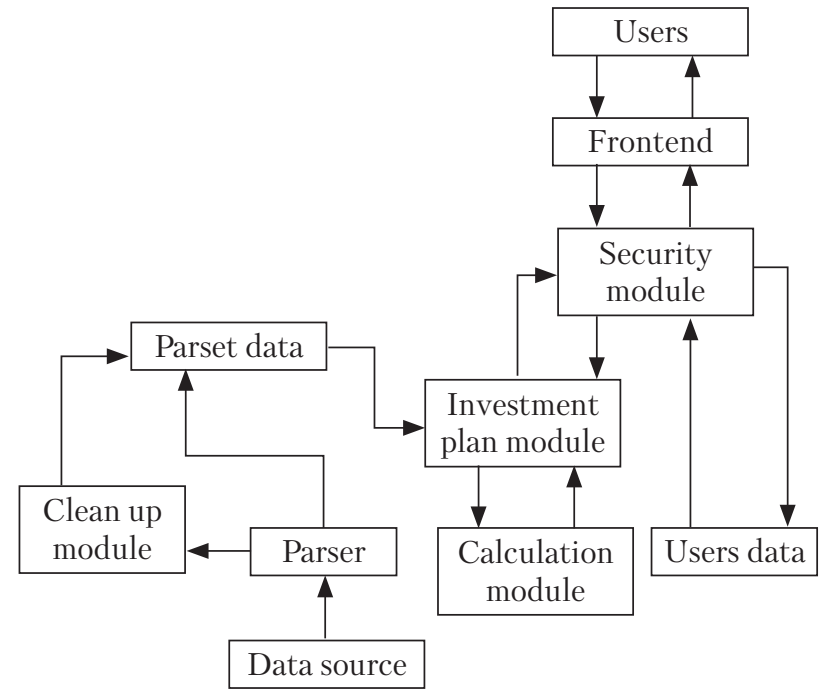

Fig. 7. Robo-Advisor architecture

The system will use these data for cluster analysis to know user's risk level (Fig. 9).

Then user has to pass the second questionnaire and answer next questions:

- From what age do you want to start your personal savings program?

- At what age do you plan to retire?

- To what age do you plan to use your personal savings program?

- What is your average annual revenue?

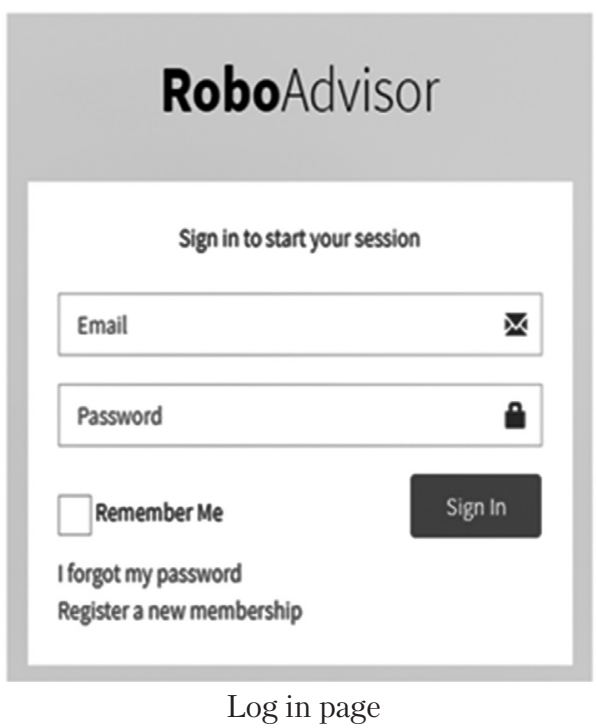

Fig. 8. Robo-Advisor creation process 


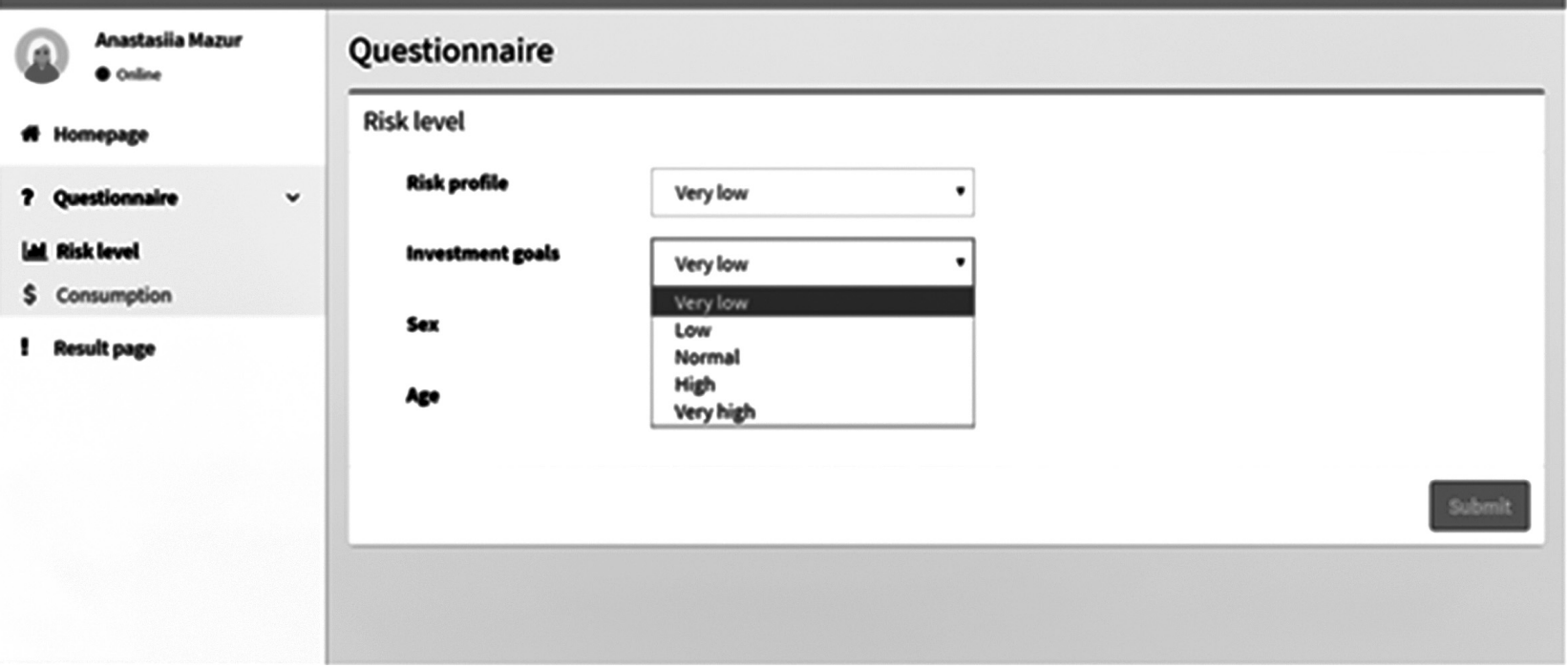

Fig. 9. First questionnaire about investor profile

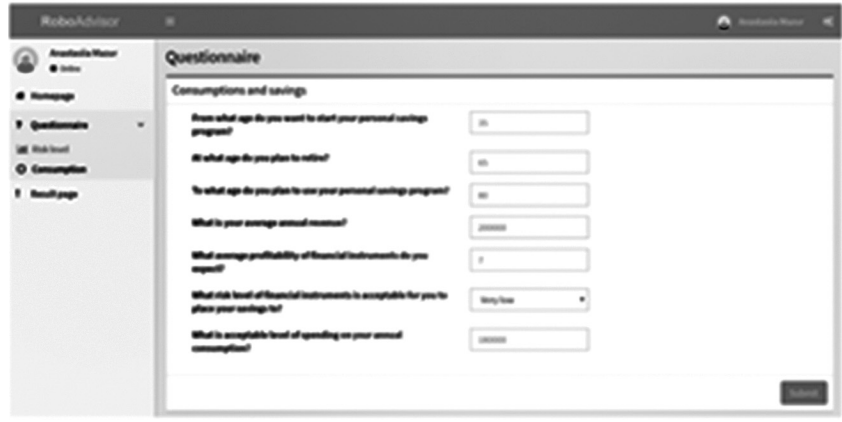

Data input

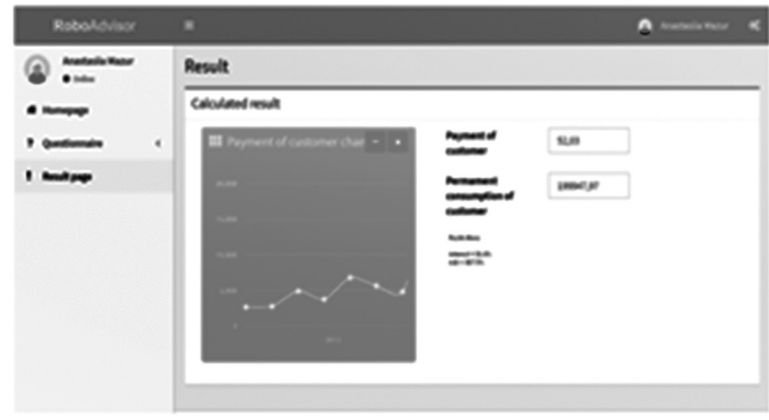

Output data

Fig. 10. Robo-Advisor: input and output

- What average profitability of financial instruments do you expect?

- What risk level of financial instruments is acceptable for you to place your savings to?

- What is acceptable level of spending on your annual consumption?

The system includes methods for calculating $S$ (Payment of customer), $C$ (Permanent consumption of client), FVA (Future Value of An Annuity), PVA (Present Value of an Annuity), provided in the application model, which uses input data, provided by the user (Fig. 10). After calculations, the system displays the calculated savings $S$ and consumption $C$ to the user during long-life period, which is based on the input data.

In the Fig. 10 are displayed results based on results of cluster analysis for representative clients: interest per year $=31.6 \%$ and risk per month $=$ $=32.3 \%$. User can modify the questionnaire data not more often, than once a week and system will automatically re-calculate the result based on new data. If payment of customer will be changed system will display it in a graph as a new breakpoint.

System will automatically send emails with notifications to customers if profitability of finan- 
cial instruments will be changed and these notifications will be displayed in the system. User can choose new investment plan and system will show potential profitability changes. For high-level risk users system will send it every day, for hybrid-level risk users - twice a week, for low-level risks users - once a week.

\section{CONCLUSIONS}

In our opinion, savings are remaining balance of disposable income directed to maintaining or improving the standard of living in the future. This fact describes an additional argument in favor of using an automated financial consultant who will assess the necessity of an immediate change in the average propensity to consume, depending on the model parameters changes. The concept of "robo-advice" means using of automation and digital techniques to build and manage portfolios of exchange-traded funds and other financial instruments for investors. Robo-adviser represents an online service that helps the client to form an investment portfolio and subsequently manage it.

The robot-adviser developed by us is designed primarily for private persons (investors) who invest for a long time in financial instruments in order to secure a permanent passive income at the planned retirement age with the help of a robot consultant. The task assignment of our IT service is to maintain a constant level of client's consumption during life-long period through automated analysis of how much he or she has to consume and save each year. To define the annual amount of savings to guarantee constant level of consumption for each private person during long life period we use present and future value of annuity.

In the future it is planned to expand the system in following directions: develop a web-based version of the application, add integration with external services to find financial instruments for investment, add administration system and improve the application interface.

\section{REFERENCES}

1. The Rise of Robo-Advice. Changing the Concept of Wealth Management. URL: https://www.accenture.com/_acnmedia/PDF-2/Accenture-Wealth-Management-Rise-of-Robo-Advice.pdf (Last accessed: 16.12.2018).

2. Park, J. Y., Ryu, J. P., Shin, H. J. (2016). Robo Advisors for Portfolio Management. Adanced Science and Technology Letters, 141 (Green and Smart Technology II), 104-108. doi: dx.doi.org/10.14257/astl.2016.141.21

3. Alós-Ferrer, C., Hügelschäfer, S., Li, J. (2016). Inertia and Decision Making. Front. Psychol., 7, 169. doi: 10.3389/ fpsyg.2016.00169

4. Park, J. H., Ryu, J. P., Shin, H. J. (2016). Predicting KOSPI Stock Index using Machine Learning Algorithms with Technical Indicators. Journal of Information Technology and Architecture, 13, 331-340.

5. The expansion of Robo-Advisory in Wealth Management - Deloitte. URL: https://www2.deloitte.com/content/dam/ Deloitte/de/Documents/financial-services/Deloitte-Robo-safe.pdf (Last accessed: 16.12.2018).

6. Jung, D., Dorner, V., Glaser, F., Morana, S. (2018). Robo-Advisory - Digitalization and Automation of Financial Advisory. Business \& Information Systems Engineering, 60(1), 81-86. doi: 10.1007/s12599-018-0521-9

7. Kohavi, R., Provost, F. (1998). Glossary of terms. Machine Learning - Special Issue on Applications of Machine Learning and the Knowledge Discovery Process. Machine Learning, 30, 271-274.

8. The implications of machine learning in finance. URL: https://www.bloomberg.com/professional/blog/implicationsmachine-learning-finance/ (Last accessed: 16.12.2018).

9. Lam, J. W. (2016). Robo-Advisers: A Portfolio Management Perspective. Senior Thesis, Yale College. URL: http://economics.yale.edu/sites/default/files/files/Undergraduate/Nominated\%20Senior\%20Essays/2015-16/Jonathan_Lam_ Senior\%20Essay\%20Revised.pdf

10. Faggella, D. Machine Learning in Finance - Present and Future Applications. URL: https://www.techemergence.com/ machine-learning-in-finance/ (Last accessed: 16.12.2018).

11. Kashner, E. Ghosts in the Robo Advisor Machine. URL: http://www.etf.com/sections/blog/22973-ghosts-in-the-roboadvisor-machine.html (Last accessed: 16.12.2018).

12. Markowitz, H. M. (1952). Portfolio Selection. The Journal of Finance. 7(1), 77-91. doi:10.2307/2975974. JSTOR 2975974 
13. Fisher, I. (1977). The Theory of interest. Philadelphia: Porcupine Press.

14. Black, F., Litterman, R. (1992). Global Portfolio Optimization. Financial Analysts Journal, 48(5), 28-43. doi:10.2469/faj. v48.n5.28

15. Baker, T., Dellaert, B. (2018). Regulating Robo Advice Across the Financial Services Industry. Faculty Scholarship at Penn Law. 1740. URL: https://scholarship.law.upenn.edu/faculty_scholarship/1740 (Last accessed: 16.12.2018)

16. Betterment Review. URL: https://www.nerdwallet.com/blog/investing/betterment-review/ (Last accessed: 16.12.2018).

17. Future Advisor Review. URL: https://www.nerdwallet.com/blog/investing/futureadvisor-review/ (Last accessed: 16.12.2018).

18. Thangavelu, P. Motif Investing Broker Review: Easy Thematic Investing. URL: https://www.investopedia.com/articles/active-trading/030415/motif-investing-broker- review-easy-thematic-investing.asp (Last accessed: 16.12.2018).

19. Motif Investment Review. URL: https://www.nerdwallet.com/blog/investing/motif-investing-review-1/ (Last accessed: 16.12.2018).

20. Fein, M. L. Robo-Advisors: a Closer Look. URL: http://dx.doi.org/10.2139/ssrn.2658701 (Last accessed: 16.12.2018).

21. Robo advising - KPMG. URL: https://home.kpmg.com/content/dam/kpmg/pdf/2016/07/Robo-Advising-CatchingUp-And-Getting-Ahead.pdf (Last accessed: 16.12.2018).

22. Kobets, V., Yatsenko, V. (2016). Adjusting business processes by the means of an autoregressive model using BPMN 2.0. CEUR Workshop Proceedings, 1614, 518-533. URL: CEUR-WS.org/Vol-1614/ICTERI-2016-CEUR-WS-Volume.pdf (Last accessed: 16.12.2018).

23. Kobets, V., Poltoratskiy, M. (2016). Using an Evolutionary Algorithm to Improve Investment Strategies for Industries in an Economic System. CEUR Workshop Proceedings, 1614, 485-501. URL: CEUR-WS.org/Vol-1614/ICTERI-2016CEUR-WS-Volume.pdf (Last accessed: 16.12.2018).

24. Snihovyi, O., Ivanov, O., Kobets, V. (2018). Implementation of Robo-Advisors Using Neural Networks for Different Risk Attitude Investment Decisions. $9^{\text {th }}$ International conference on intelligent systems, (25-27 September 2018, FunchalMadeira, Portugal), Funchal-Madeira, 2018, 332-336. doi:10.1109/is.2018.8710559 (Last accessed: 16.12.2018).

25. Kobets, V., Yatsenko, V., Mazur, A., Zubrii, M. (2018). Data Analysis of Private Investment Decision Making Using Tools of Robo-Advisers in Long-Run Period. CEUR Workshop Proceedings, 2104, 144-159. URL: CEUR-WS.org/Vol-2104/ (Last accessed: 16.12.2018).

Received 04.01.19

Revised 10.04.19

Accepted 07.05.19

В.М. Кобець ${ }^{1}$, В.О. Яиенко ${ }^{2}$, А.Ю. Мазур, М.І. Зубрій

${ }^{1}$ Херсонський державний університет, вул. Університетська, 27, Херсон, 73003, Україна, +380552 32 6782, kipiekedu@gmail.com

${ }^{2}$ Київський національний університет імені Тараса Шевченка, вул. Васильківська, 90-А, Київ, 03022, Україна,

+380 44521 3578, decanat_econom@univ.kiev.ua

\section{АНАЛІЗ ДАНИХ ПЕРСОНАЛІЗОВАНОГО ПРИЙНЯТТЯ ІНВЕСТИЦЙНИХ РІШЕНЬ З ВИКОРИСТАННЯМ АВТОМАТИЗОВАНИХ ФІНАНСОВИХ КОНСУЛЬТАНТІВ}

Вступ. На сьогодні проблема пошуку оптимального балансу між споживанням та заощадженнями, перетвореними в інвестиції, вирішується за допомогою автоматизованих систем прийняття інвестиційних рішень, прикладом яких є послуги автоматизованих фінансових консультантів або робо-консультантів (robo-advisers), які працюють на базі математичного алгоритму, що грунтується на теорії споживання та заощадження.

Проблематика. Завданням розробленого IT сервісу є підтримка постійного рівня споживання клієнта протягом всього періоду життя шляхом автоматичного аналізу того, скільки він/вона має споживати та заощаджувати щороку. Результати пропозицій щодо співвідношення споживання та заощадження можуть змінюватися при зміні початкових фінансових даних.

Мета. Розробити інвестиційний план для профайлів інвесторів з урахуванням їх схильності до ризику за допомогою аналізу даних сервісом автоматизованих фінансових консультантів (robo-advisers). 
Матеріали і методи. SWOT-аналіз послуг робо-консультантів (RA) та порівняльні характеристики робо-консультантів пояснюють переваги сервісу RA. Мікросервіс для розрахунку стабільного рівня споживання і модель фінансового консультування робо-консультанта для гарантування стабільного рівня споживання клієнта розроблено з використанням низки технологій: Python 3.6, Django 2.0, Django Rest framework, AngularJs, HTML5, CSS 3, Bootstrap.

Результати. Розглянуто співвідношення споживання-заощадження, нові тенденції послуг робо-консультантів (RA) використовуваних для прийняття інвестиційних рішень. Розроблено математичну модель робо-консультанта в довгостроковій перспективі та описано підтримку прийняття інвестиційного рішення в довгостроковій перспективі за участі програмного модуля робо-консультанта.

Висновки. Розробку RA призначено, насамперед, для приватних осіб (інвесторів), які інвестують у довгострокові фінансові інструменти, з метою забезпечення їхнього постійного пасивного доходу на основі обраного ними періоду заощадження і моменту виходу на пенсію.

Ключові слова: робо-консультант, аналіз даних, довгострокове прийняття рішень, ануїтет. 